\title{
Lipase from thermoalkalophilic Pseudomonas species as an additive in potential laundry detergent formulations
}

\author{
Khoo, M. L.* and Ibrahim, C. O \\ Fermentation and Enzyme Technology Laboratory, School of Biological Sciences, \\ Universiti Sains Malaysia, 11800 Minden Penang, Malaysia. \\ E-mail: miewleng78@yahoo.com
}

Received 20 November 2007; received in revised form 22 August 2008; accepted 22 August 2008

\begin{abstract}
Lipase isolated from a thermoalkalophilic Pseudomonas species was used as additive to improve the degree of olive oil removal from cotton fabric in the presence of surfactants. The lipase used in this study was found to be more effective with non ionic surfactants as compared to ionic surfactants. In terms of stability, there was no decrease in activity found in the presence of Tween 85, Span 80 and Span 20. Lipase from Pseudomonas species was most active in the presence of Tween 85, Span 80 and Span 20. The application of lipase from Pseudomonas species as an additive in the formulation containing Span 80 has improved oil removal by $36 \%$ using the washing system consisting $5 \mathrm{U} / \mathrm{mL}$ lipase, at $70{ }^{\circ} \mathrm{C}$ for $20 \mathrm{~min}$ and $0.8 \%$ of Span 80 as surfactant. Considering that lipase from Pseudomonas species is stable in high $\mathrm{pH}$ and temperatures in the presence of various surfactants, therefore it is suitable to be incorporated as additives in potential detergent formulations.
\end{abstract}

Keywords: Pseudomonas species, degree of olive oil removal, Span 80, lipase

\section{INTRODUCTION}

One of the most important applications of thermotolerant alkaline lipases include additives in detergent formulations because detergent enzymes need to be stable in the alkaline washing conditions in the presence of surfactants. Enzymes used in the detergent industry also have to be thermostable so that it is able to function at a high temperature due to generation of heat and also to enable efficient operation at higher temperatures normally practiced in the industry. The first alkaline lipase which is known as Lipolase was introduced by Novo in the year 1988 (Crutzen and Douglass, 1999). In the year 1993 and 1995, two lipases from Genencor which are known as Lumafest and Lipomax were isolated from a Pseudomonas species which were further modified through genetic engineering and used in the detergent industry. Lipase from Pseudomonas species is suitable for the formulation of detergent because it is active at alkaline $\mathrm{pH}$ and also able to withstand high temperatures (Soberon-Chavez and Palmer, 1994). Lipase from Pseudomonas alcaligenes which has a high alkaline tolerance is beneficial to be used in modern washing conditions. Hence, Gerritse et al. (1998) has optimized gene expression in the natural host of Pseudomonas alcaligenes to enable fermentation processes at alkaline $\mathrm{pH}$. Only a low concentration of enzyme (normally $1 \mathrm{ppm}$ ) is sufficient to loosen adhesion or proteinaeous matter.

In 1913, Tilburg (1984) has announced that enzymes was introduced in washing when Otto Rohm was awarded the German patent for a soaking product which contains enzymes from animal pancreatic glands. The first product containing enzymes is a detergent which is launched in Germany known as Burnus. In the 1960s, enzymes was used in the detergent industry as soaking powder and later on for the removal of proteinaceous dirt. As a result of the enzyme reaction, dirt becomes more easily soluble and is removed more easily by surfactants. Besides that, enzymes also help to maintain fabric properties such as brightness, whiteness, softness and smooth fabric texture (Crutzen and Douglass, 1999). Enzymes are widely used in the detergent industry due to a few characteristics such as effectiveness at a low concentration, low cost and does not pollute the environment. It is essential for enzymes to possess a few characteristics for application in detergents such as a high optimum $\mathrm{pH}$, effective at washing temperatures between 20 to $40{ }^{\circ} \mathrm{C}$ and stable in washing conditions until $60{ }^{\circ} \mathrm{C}$ (Crutzen and Douglass, 1999). Anwar and Saleemudin (2000) has shown that the crude extract of Spilosoma obliqua which contains protease, amylase and lipase can be used as additives in detergents because these enzymes are found to be very effective in the removal of blood stains with or without the presence of detergent.

Lipase is used in the detergent industry to remove sebum from fabric which is difficult to be removed in normal washing conditions. Lipase hydrolyzes triglycerides to di- and monoglycerides and free fatty acids. During the removal of the glycerides in alkaline surfactants, free fatty acid are removed easily through the formation of soapy fatty acids which are water soluble but triglycerides are not saponified by the alkaline solution

\section{${ }^{*}$ Corresponding author}


and therefore still remains on the fabric. There are a few factors which affect the activity and stability of enzymes in washing conditions such as time, presence of surfactants, fabric and temperature. Surfactants are the most important component in detergents. Surfactants aid in the removal of dirt after being hydrolyzed by enzymes during washing. In the search for lipase as an additive for potential laundry detergent application, this paper highlights the incorporation of lipase from Pseudomonas species in washing systems containing surfactants to study the degree of oil removal.

\section{MATERIALS AND METHODS}

Lipase from a thermoalkalophic Pseudomonas species isolated from the hot spring of Ulu Lenggong, Kedah was used in this study. The lipase activity was determined by adding $7 \mathrm{mg}$ surfactant into the reaction mixture. Control refers to reaction mixture without surfactants. Stability of lipase was determined by incubation of $5 \mathrm{~mL}$ lipase with 5 $\mathrm{ml}$ surfactant solution ( $35 \mathrm{mg}$ surfactant $/ 5 \mathrm{~mL}$ buffer) in $0.05 \mathrm{M}$ Clark and Lubs buffer (pH 8.0) for $1 \mathrm{~h}$. $1 \mathrm{~mL}$ incubation solution was taken out and lipase activity was determined at $45^{\circ} \mathrm{C}$ using $0.05 \mathrm{M}$ glycine buffer $(\mathrm{pH}$ 9.0) and olive oil substrate: polyvinyl alcohol 1:3 for $30 \mathrm{~min}$. The relative activity was calculated relative to the control which was $100 \%$. Test was carried out to determine the effect of lipase in washing fabric spotted with olive oil (Hemachander and Puvanakrishnan, 2000). Cotton fabric was cut to the size of $5 \mathrm{~cm} \times 10 \mathrm{~cm}$ and was defatted by boiling in chloroform for $1 \mathrm{~h}$. The cotton fabric was then rinsed and dried. $0.5 \mathrm{~mL}$ mixture of olive oil: benzene at a concentration of $100 \mathrm{mg} / \mathrm{mL}$ was spotted twice at a volume of $1 \mathrm{ml}$ on the cotton fabric that was dried. The quantity of olive oil for a fabric measurement of $5 \mathrm{~cm} \times 10$ $\mathrm{cm}$ was $100 \mathrm{mg}$. The cotton fabric which was spotted with olive oil was used to determine the effect of alkaline lipase added in the washing solution.

Four washing solutions were being prepared as shown in Table 1. $40 \mathrm{~mL}$ of $0.05 \mathrm{M}$ Clark and Lubs buffer, $\mathrm{pH} 8.0$ and $50 \mathrm{~mL}$ surfactant solution containing Triton-X, $\mathrm{H}_{2} \mathrm{O}_{2}$, Tween 20, Tween 85, Span 20, Span 80 and sodium dodecyl sulphate (SDS), at a concentration of $1 \%$ (w/v) were incubated at $40^{\circ} \mathrm{C}$ for 10 minutes followed by addition of $3 \mathrm{~mL}$ of lipase having an activity of $3 \mathrm{U} / \mathrm{mL}$. Buffer-Lipase $(B+L)$, Buffer-Surfactant $(B+S)$, BufferLipase-Surfactant $(B+L+S)$ and buffer $(B)$ was prepared in the same way and the volume of final solution was adjusted to $100 \mathrm{~mL}$ with the addition of distilled water. 10 pieces of fabric which were spotted with olive oil were put into conical flasks which contained washing solutions (Hemachander and Puvanakrishnan, 2000). Spotted fabrics were washed at $40{ }^{\circ} \mathrm{C}$ with Clark and Lubs buffer, $\mathrm{pH} 8.0$ with agitation at $100 \mathrm{rpm}$ for $30 \mathrm{~min}$. The washing solution was then poured away and the fabrics were rinsed twice with $100 \mathrm{~mL}$ distilled water at $40^{\circ} \mathrm{C}$ for $3 \mathrm{~min}$. The efficiency of washing was determined by the degree of olive oil removal which was spotted on the cotton fabric. The initial weight of cotton fabric was determined. The weight of fabric which was spotted with olive oil was also determined. After washing, the fabric was air dried and the weight of the cotton fabric was determined. Two replicates were used for each experiment unless otherwise stated. Degree of olive oil removal was determined as follows:

Degree of olive $=$ Weight of olive oil before washing oil removal (\%) - Weight of olive oil after washing $\times 100$ Weight of olive oil before washing

Table 1: Composition of washing solution

\begin{tabular}{lccll}
\hline Washing solution & \multicolumn{3}{c}{ Solution $(\mathbf{m L})$} \\
\cline { 2 - 5 } & B & L & S & DW \\
\hline B & 40 & - & - & 60 \\
B + L & 40 & 3 & - & 57 \\
B+S & 40 & - & 50 & 10 \\
$B+L+S$ & 40 & 3 & 50 & 7 \\
\hline
\end{tabular}

$\mathrm{B}=0.05 \%$ Clark and Lubs buffer, $\mathrm{pH} 8.0 ; \mathrm{L}=$ Lipase $(3 \mathrm{U} / \mathrm{mL}) ; \mathrm{S}=1 \%$ Surfactant; DW= distilled water

\section{RESULTS AND DISCUSSION}

Surfactants are surface active agents which are composed of one group of molecules which are able to change the interfacial characteristics in an aqueous or non-aqueous solution (Crutzen and Douglass, 1999). However, detergent is a mixture of substances which is used in washing. Besides stability towards temperature and $\mathrm{pH}$, the lipase which is being incorporated into detergent formulation also has to be stable in the presence of surfactants and whitening agents. The lipase which was used in this study was stable in most inorganic surfactants. In terms of stability, there was no decrease in activity found in the presence of Tween 85, Span 80 and Span 20. From Figure 1, it was observed that lipase was not stable in Tween 20 and the stability in whitening agent $\left(\mathrm{H}_{2} \mathrm{O}_{2}\right)$ was also quite low. From Figure 1, it was also shown that sodium dodecyl sulphate (SDS) inhibited lipase with $75 \%$ loss of activity as compared to the control. Lipase from Pseudomonas species was most active in the presence of Tween 85, Span 80 and Span 20. It was also found that there was $50 \%$ lost of lipase activity in the presence of Triton-X, Tween 20 and $\mathrm{H}_{2} \mathrm{O}_{2}$. The inhibition of SDS on lipase activity showed that there was a possibility that negatively charged detergents (anions) obstructed lipase from the interface, combined with the enzyme or coated it so that the site for substrate adhesion was being obstructed. The same result was being observed from the lipase from Candida cylindracea by Fujii et al (1986) whereby lipase was enhanced in the presence of non ionic detergents as compared to anions. Therefore, lipase was found to be more effective with non ionic surfactants as compared to ionic surfactants.

However, in the study of removal of olive oil from cotton fabric, non ionic surfactant such as Span 80 was found to be more effective in the presence of lipase (Figure 2). In an earlier study, the presence of lipase from 
Pseudomonas glumae was also found to be efficient in a system of washing model (lizumi et al., 1991, Jorgesen et al., 1991). Span 80 was chosen for the following studies as it showed the highest percentage of oil removal in the presence of lipase. The study on the effect of lipase concentration on the removal of olive oil from cotton fabric with Span 80 showed that oil removal increased with the increase in lipase concentration. Removal of olive oil increased slowly with the increase of lipase concentration (Fujii et al., 1986). From Figure 3, it was shown that addition of lipase above $3 \mathrm{U} / \mathrm{mL}$ increased the removal of olive oil. It was also observed that the degree of olive oil removal reached maximum $(70 \%)$ when $5 \mathrm{U} / \mathrm{mL}$ enzyme was being incorporated into the washing system.

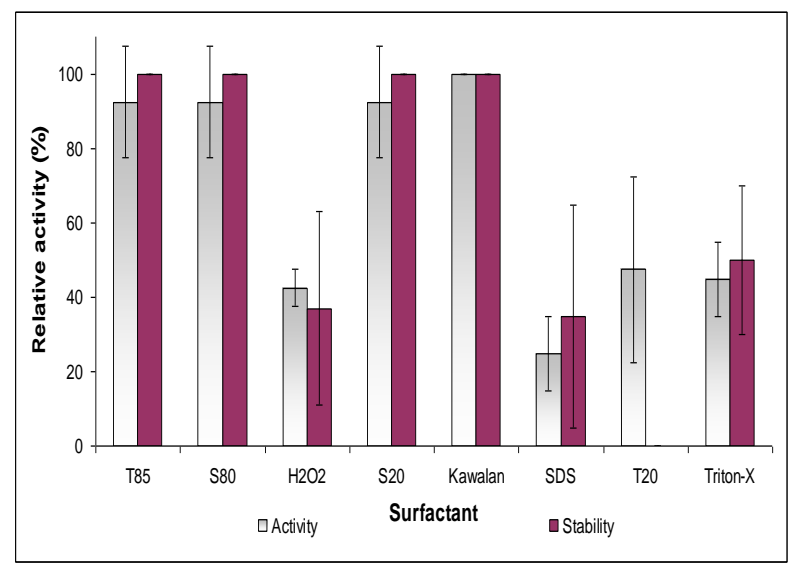

Figure 1: Effect of surfactants on the activity and stability of lipase

Note: Bars show the average error between two duplicate readings T85-Tween 85, S80-Span 80, $\mathrm{H}_{2} \mathrm{O}_{2}$-Hydrogen Peroxide, S20-Span 20, SDS-Sodium dodecyl sulphate, T20-Tween 20

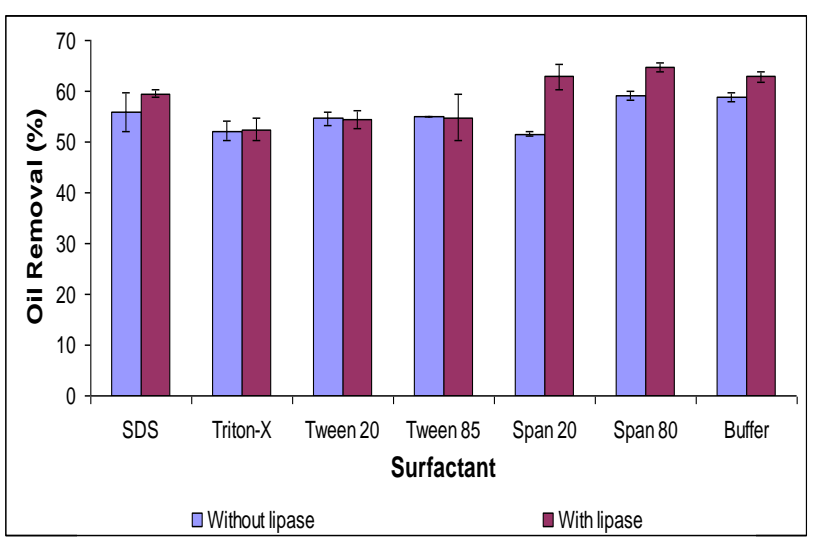

Figure 2: Effect of lipase as additive in various surfactants

Note: Bars show the average error between two duplicate readings

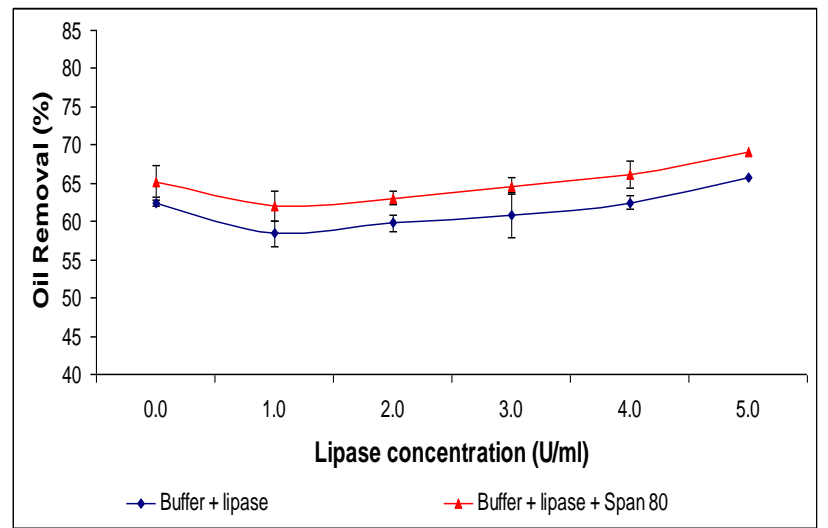

Figure 3: Effect of lipase concentration on the removal of olive oil

Note: Bars show the average error between two duplicate readings

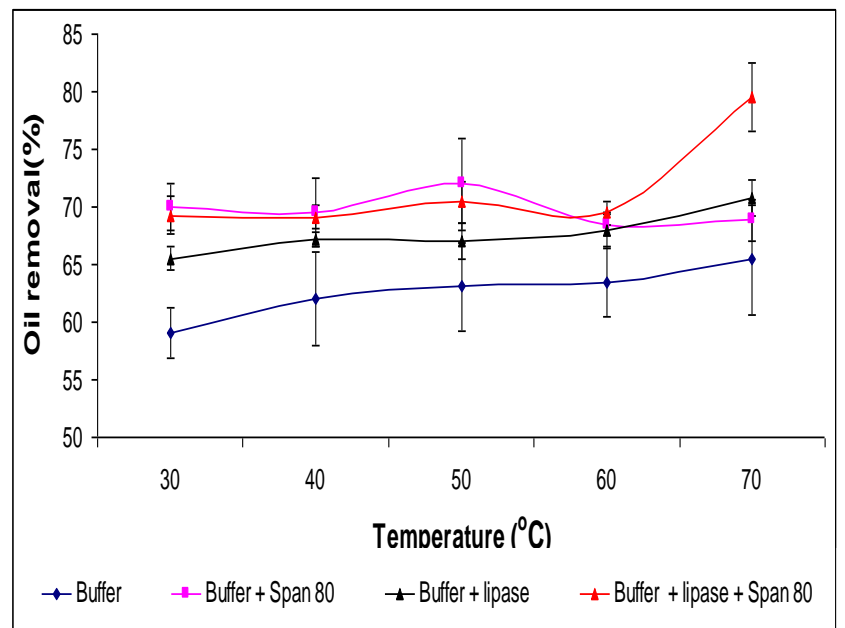

Figure 4: Effect of temperature on the removal of olive oil

Note: Bars show the average error between two duplicate readings

For the washing system which contained lipase and Span 80 , removal of olive oil was increased above $40^{\circ} \mathrm{C}$. From Figure 4, it was observed that $70{ }^{\circ} \mathrm{C}$ showed the highest percentage of oil removal. This can be correlated with the stability of lipase from Pseudomonas species which was maintained $100 \%$ at $70{ }^{\circ} \mathrm{C}$. This can also be compared with the study of lipase from Candida cylindracea whereby increase in olive oil removal was evident with increase in temperature above $60^{\circ} \mathrm{C}$ (Fujii et al., 1986). Hemachander and Puvanakrishnan (2000) also reported that removal of oil by lipase from Ralstonia picketti increased with the increase in temperature. The degree of oil removal with buffer and Span 80 was better as compared to buffer alone. The effectiveness of enzyme depends on temperature which affects the rate of dissolution, activity and stability in washing solutions. The 
rate of dissolution is higher at a higher temperature. Hence, the thermostable lipase from Pseudomonas species was suitable for industrial processes which are operated at high temperatures and also in washing machines which generate a lot of heat. The method of washing around the world is divided into three segments; hot washing zones (Europe), moderate washing zones (America) and cold washing zones normally Japan and South East Asia (Nielsen et al., 1981). Enzyme activity increases with increase in temperature whereby the rate of enzyme detergent reaction doubles with increase of $10^{\circ} \mathrm{C}\left(18^{\circ} \mathrm{F}\right)$ in temperature. Normally cotton material is washed at higher temperatures $\left(60\right.$ to $\left.90^{\circ} \mathrm{C}\right)$ compared to synthetic material (40 to $60^{\circ} \mathrm{C}$ ) (Crutzen and Douglass, 1999).

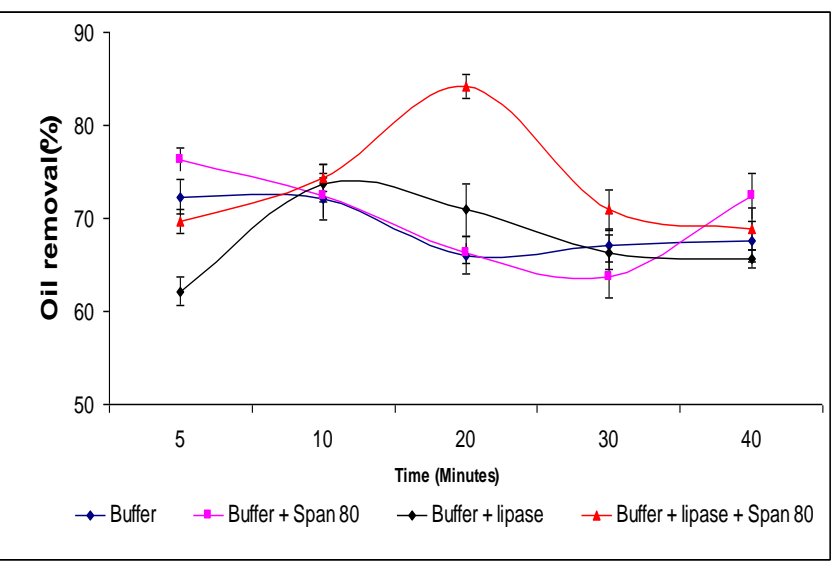

Figure 5: Effect of time on the removal of olive oil

Note: Bars show the average error between two duplicate readings

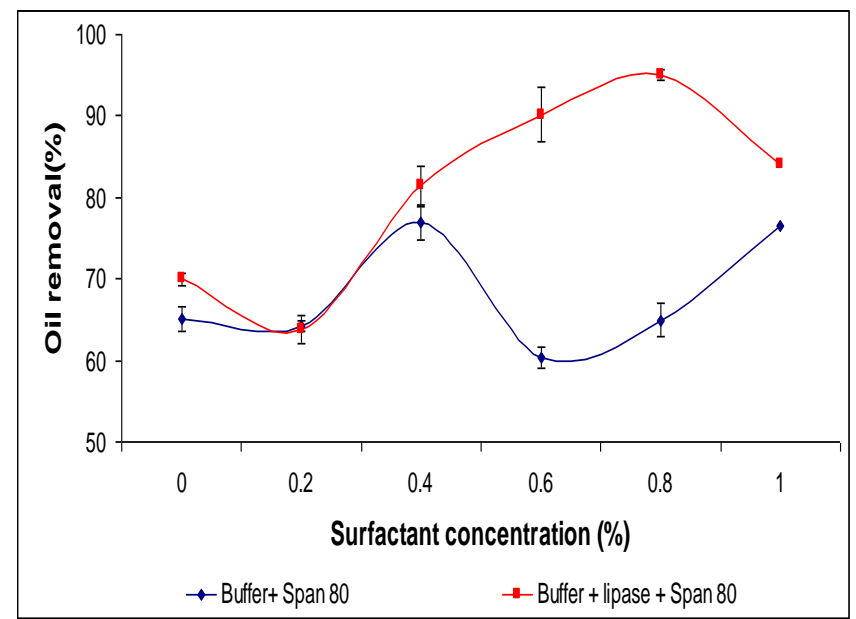

Figure 6: Effect of Surfactant concentration on the removal of olive oil

Note: Bars show the average error between two duplicate readings

The effect of time on olive oil removal showed that 20 min was the optimum time with $85 \%$ olive oil removal
(Figure 5). This result can also be compared with the study of the effect of lipase from Ralstonia pickettii as additive in the formulation of detergent whereby 20 minutes was also found to be the optimum time (Hemachander and Puvanakrishnan, 2000). However, Figure 5 showed that percentage of oil removal decreased at $30 \mathrm{~min}$. This might be due to the reattachment of the removed oil to the cotton fabric with prolonged washing. The activity and stability of enzymes depend on $\mathrm{pH}$ and temperature of the washing solution, time of reaction of the fabric and the washing solution which contains enzyme and whitening agents (Crutzen and Douglass, 1999).

The optimum concentration for Span 80 was $0.8 \%$ with $95.07 \%$ olive oil removal (Figure 6). In any concentration of surfactant, it was found that the degree of oil removal was higher in the washing solution containing Span 80 in the presence of lipase as compared with the solution without lipase (Figure 6).

\section{CONCLUSIONS}

In conclusion, the addition of lipase has increased olive oil removal up to $36 \%$ as compared with the washing system without lipase. This study has shown that lipase from Pseudomonas species has improved olive oil removal from cotton fabric in the presence of Span 80 as a surfactant under conditions of $5 \mathrm{U} / \mathrm{mL}$ lipase concentration, $70{ }^{\circ} \mathrm{C}$, washing time of $20 \mathrm{~min}$ and $0.8 \%$ concentration of Span 80. Considering that lipase from Pseudomonas species is stable in high $\mathrm{pH}$, temperatures and in the presence of various surfactants, therefore it is suitable to be incorporated as additives in potential detergent formulations.

\section{ACKNOWLEDGEMENT}

The financial support under SIRIM is highly appreciated.

\section{REFERENCES}

Anwar, A. and Saleemudin, M. (2000). Alkaline protease from Spilosoma obliqua: potential applications in bioformulations. Biotechnology and Applied Biochemistry 31, 85-89.

Crutzen, A. and Douglas, M. L. (1999). Detergent enzymes: A challenge! Broze, G. (ed.) in Handbook of Detergents. New York.

Fujii, T., Tatara, T. and Minagawa, M. (1986). Studies on applications of lipolytic enzyme in detergency. Effect of lipase from Candida cylindracea on removal of olive oil from cotton fabric. Journal of the American Oil Chemists' Society 63, 796-799.

Gerritse, G., Hommes, R. W. and Quax, W. J. (1998). Development of a lipase fermentation process that uses a recombinant Pseudomonas alcaligenes strain. Applied and Environmental Microbiology 64, 26442651. 
Hemachander, C. and Puvanakrishnan, R. (2000). Lipase from Ralstonia pickettii as an additive in laundry detergent formulations. Process Biochemistry. 35, 809-881.

lizumi, T., Nakamuram, K., Shimada, Y., Sugihara, A., Tominaga, Y. and Fukase, T. (1991). Cloning, nucleotide sequencing, and expression in Escherichia coli of a lipase and its activator genes from Pseudomonas KW1-56. Agricultural and Biological Chemistry 55, 2349-2358.

Jorgesen, S., Skov, K. W. and Diderichsen, B. (1991). Cloning, sequence and expression of a lipase gene from Pseudomonas cepacia: lipase production in heterologous hosts requires two Pseudomonas genes. Journal of Bacteriology 173, 559-564.

Nielsen, M. H., Jepsen, S. and Outtrup, H. (1981). Enzymes for low temperature washing. Journal of the American Oil Chemists' Society 58, 644-649.

Soberon-Chavez, G. G. and Palmeros, B. (1994). Pseudomonas lipases: molecular genetics and potential industrial applications. Critical Reviews in Microbiology 20, 95-105.

Tilburg, R. V. (1984). Enzymes in powdered and liquid laundry detergents. In: Innovations in Biotechnology. Houwink, E. H. and Meer, R. R. (eds.) The Netherlands: Elsevier, pp.31-51. 